\begin{abstract}
Iranica
Abstracta Iranica Revue bibliographique pour le domaine irano-aryen

Volume 40-41 | 2019

Comptes rendus des publications de 2017-2018
\end{abstract}

\title{
Ludwig Paul (ed.). Handbuch der Iranistik, Band 2
}

\section{Jürgen Paul}

\section{OpenEdition}

\section{Journals}

\section{Édition électronique}

URL : http://journals.openedition.org/abstractairanica/50491

DOI : 10.4000/abstractairanica.50491

ISBN : 1961-960X

ISSN : 1961-960X

Éditeur :

CNRS (UMR 7528 Mondes iraniens et indiens), Éditions de l'IFRI

Référence électronique

Jürgen Paul, « Ludwig Paul (ed.). Handbuch der Iranistik, Band 2 », Abstracta Iranica [En ligne], Volume 40-41 | 2019, document 4, mis en ligne le 30 décembre 2019, consulté le 17 avril 2021. URL : http:// journals.openedition.org/abstractairanica/50491 ; DOI : https://doi.org/10.4000/abstractairanica. 50491

Ce document a été généré automatiquement le 17 avril 2021.

Tous droits réservés 


\title{
Ludwig Paul (ed.). Handbuch der Iranistik, Band 2
}

\author{
Jürgen Paul
}

\section{RÉFÉRENCE}

Ludwig Paul (ed.). Handbuch der Iranistik, Band 2. Wiesbaden : Reichert, 2017. 550p.

1 This volume completes and complements the first volume of this standard work of reference for the entire field which appeared in 2013 (see Abstracta Iranica 34-35-36, review by Agnes Korn, under 2.Linguistique, 2.0 Généralités no. 5). Like the first, the second volume is organised in eight main chapters, History, Contemporary Iranian World, Law, Religion, Language, Literature, Manuscriptology, Art - Architecture Archeology, and in this volume, two chapters are added: Philosophy and the exact sciences, and Music. For a detailed review of both works, see Rudi Matthee's article in Iranian Studies 52.1-2 (2019), 247-52.

2 There are 58 contributions in all which again range from less than ten to about twenty pages. All of them follow the same structure as in volume 1: there is a general introduction followed by an account of (recent and sometimes not so recent) research, and at the end, a comprehensive bibliography. The volume ends with an index including personal and placenames as well as technical terms.

3 The second volume excels in various respects. First, it gives more attention to countries and regions thought to be on the periphery of the Iranian world: Tajikistan, for instance, is very well served in history as well as literature, and there is a competent analysis of contemporary Tajikistan (meaning evidently a period until roughly 2015). There are quite a number of contributions on Kurdistan and Afghanistan as well. NonPersian literatures (in Iran or elsewhere) include Kurdish, Pashto, Tajik, Baluch, and Ossetian; for Persian there are chapters on modern theater, travel literature, and literature written by emigrants. In these chapters, readers will find really innovative aspects: some questions and fields have not been treated in encyclopedic works at all. 
Some contributions impressed me in particular: on the security apparatus of the Islamic Republic of Iran (Walter Posch); the history of Tajikistan (Thomas Loy) and the contemporary history of that country (Jeanine Dağyeli), the very well informed sections on gender, in particular in Islamic Iran (Ramin Shaghaghi). In the history section, there is a highly useful contribution on historiography (Tilmann Trausch) and one on auxiliary sciences in history (Christoph Werner).

5 This two-volume set is an enormous achievement, and it will stand for quite a while. Contributors draw on research from a wide range of languages (including research done in Iran and other countries of the Iranian world). Russian is well represented in the relevant contributions, above all on Tajikistan and Afghanistan. It is a pity that Christoph Werner did not note the major contributions made by Soviet and Russian researchers to the fields which are called istochnikovedenie (source science) in Russian.

6 The two volumes expand the concept of Iranistik to include not only Iranian languages and literatures, but the entirety of humanities and social sciences as far as they are connected in any way to Iran or any other Iranian-speaking country or region. There is a critical note about that in Heidrun Eichner's contribution on philosophy in the Islamic period: is this field part of Iranistik because the authors perhaps spoke an Iranian language at home (many of the works are in Arabic), or because they lived in a country which is today part of the Iranian world? This is a good question, but it would be a pity if it had led the author not to write it: the article is a masterpiece of clarity, and therefore we are glad to have it.

7 It would be good if the publisher could try to get the two-volume set translated - the fact that all contributions are in German will restrict its readership. The scholarly value of the Handbuch der Iranistik without doubt warrants the effort.

\section{AUTEURS}

\section{JÜRGEN PAUL}

Martin Luther University Halle-Wittenberg 